\title{
Impact of copper toxicity on stone-head cabbage (Brassica oleracea var. capitata) in hydroponics
}

Sajid Ali, Muhammad Shahbaz, Ahmad Naeem Shahzad, Hafiz Azhar Ali Khan, Moazzam Anees, Muhammad Saleem Haider, Ammara Fatima

Arable soils are frequently subjected to contamination with copper as the consequence of imbalanced fertilization with manure and organic fertilizers and/or extensive use of copper-containing fungicides. In the present study, the exposure of Stone-head cabbage (Brassica oleracea Var. capitata) to elevated $\mathrm{Cu}^{2+}$ levels resulted in leaf chlorosis and lesser biomass yield at $\geq 2 \mu \mathrm{M}$. Root nitrate content was not statistically affected by $\mathrm{Cu}^{2+}$ levels, although it was substantially decreased at $\geq 5 \mu \mathrm{M} \mathrm{Cu^{2+ }}$ in the shoot. The decrease in nitrate contents can be related to lower nitrate uptake rates because of growth inhibition by Cu-toxicity. Shoot sulfate content increased strongly at $\geq 2 \mu \mathrm{M} \mathrm{Cu}{ }^{2+}$ indicating an increase in demand for sulfur under Cu stress. Furthermore, at $\geq 2 \mu \mathrm{M}$ concentration, concentration of water-soluble non-protein thiol increased markedly in the roots and to a smaller level in the shoot. When exposed to elevated concentrations of $\mathrm{Cu}^{2+}$ the improved sulfate and water-soluble non-protein thiols need further studies for the evaluation of their direct relation with the synthesis of metal-chelating compounds (i.e. phytochelatins). 


\section{Impact of copper toxicity on stone-head cabbage (Brassica oleracea}

3 Sajid Ali ${ }^{* 1}$, Muhammad Shahbaz ${ }^{1,2}$, Ahmad Naeem Shahzad ${ }^{3}$, Hafiz Azhar Ali Khan ${ }^{1}$, Moazzam

4 Anees $^{1}$, Muhammad Saleem Haider ${ }^{1}$ and Ammara Fatima ${ }^{4}$

$6{ }^{1}$ Institute of Agricultural Sciences, University of the Punjab, Lahore 54590, Pakistan.

7 2Biology Department, Colorado State University, Fort Collins, Colorado 80523, USA

8 32Department of Agronomy, Bahauddin Zakaryia University, Multan, Pakistan.

9 4Department of Environmental Science, Lahore College for Women University, Lahore, 10 Pakistan.

\section{Corresponding Author:}

Address:

Institute of Agricultural Sciences, University of the Punjab, Lahore-54590

\section{Email address: $\quad$ sajid.iags@pu.edu.pk}

\section{ABSTRACT}

Arable soils are frequently subjected to contamination with copper as the consequence of imbalanced fertilization with manure and organic fertilizers and/or extensive use of coppercontaining fungicides. In the present study, the exposure of Stone-head cabbage (Brassica oleracea var. capitata) to elevated $\mathrm{Cu}^{2+}$ levels resulted in leaf chlorosis and lower biomass production at $\geq 2 \mu \mathrm{M}$. The nitrate content of the root was not affected at all $\mathrm{Cu}^{2+}$ levels, whereas that was substantially decreased at $\geq 5 \mu \mathrm{M} \mathrm{Cu}^{2+}$ in the shoot. The decrease in nitrate contents can be related to lower nitrate uptake rates because of growth inhibition by $\mathrm{Cu}$-toxicity. The sulfate content of the shoot strongly increased at $\geq 2 \mu \mathrm{M} \mathrm{Cu}^{2+}$ indicating an increase in demand for sulfur under $\mathrm{Cu}$ stress. Moreover, there was a noticeable increase in water-soluble non-protein thiol content in the root and to a lesser extent in the shoot at $\geq 2 \mu \mathrm{M}$. Enhanced sulfate and 
30 study to evaluate their direct relation with the synthesis of metal-chelating compounds (i.e. 31 phytochelatins).

32 Keywords: Leaf chlorosis, non-protein thiol, nutrient uptake, $\mathrm{Cu}$ contamination, biomass, 33 Copper; Toxicity; Brassica; Cabbage; Sulfur; Thiols; Hydroponics

34 Short Title: Copper toxicity in Stone-head cabbage in hydroponics

\section{INTRODUCTION}

Transition metals such as copper $(\mathrm{Cu})$, zinc $(\mathrm{Zn})$ and molybdenum $(\mathrm{Mo})$ are essential for the growth and development of plants, but they rapidly get toxic at higher levels (Kopsell and Kopsell, 2007). $\mathrm{Cu}$ contamination in agricultural soils as a consequence of mining metals, dispersal of sewage sludge, arbitrary and improper application of agrochemicals, addition of organic fertilizers and frequent use of irrigation with low quality water is a well-known problem (Dach and Starmans, 2005; Yruela, 2009). Cu being redox active metal can exist in both $\mathrm{Cu}^{2+}$ and $\mathrm{Cu}^{+}$forms in living organisms. At the protein level, $\mathrm{Cu}$ serves as a co-factor for various enzymes such as $\mathrm{Cu} / \mathrm{Zn}$-superoxide dismutase $(\mathrm{Cu} / \mathrm{ZnSOD})$, cytochrome c oxidase, ascorbate oxidase, amino oxidase, laccase, plastocyanin (PC), and polyphenol oxidase (Yruela, 2005; 2009; Pilon et al., 2006). However, redox cycling between $\mathrm{Cu}^{2+}$ and $\mathrm{Cu}^{+}$could induce oxidative stress by producing highly toxic hydroxyl radicals (Yruela, 2005, 2009).

Plants exposed to elevated levels of $\mathrm{Cu}$ show unspecific toxicity symptoms. Elevated $\mathrm{Cu}$ levels in soils primarily result in stunted root growth and leaf chlorosis (Kopsell and Kopsell, 2007; Shahbaz et al., 2010a). Copper toxicity-induced reduction in chlorophyll contents hinder the development of chloroplast, thalakoid membrane and photosystem II (PSII), which are considered as the most sensitive Cu toxicity sites (Pätsikkä et al., 1998, 2002; Burkhead et al., 2009; Yruela, 2005, 2009; Shahbaz et al., 2010b). At cellular level, toxicity may lead to binding of sulfhydryl groups in proteins, insufficiency or excess of other essential ions, oxidative damage and reduced cell transport (De Vos et al., 1993; Yruela, 2009). Furthermore, Cu-toxicity can change the mineral composition of plants i.e. for instance, Fe contents may decrease in the shoot (Pätsikkä et al., 1998; 2002; Kopsell and Kopsell, 2007; Shahbaz et al., 2010b), Ca and Mg may decrease in the root and $\mathrm{Zn}$ contents may increase in both root and shoot upon $\mathrm{Cu}$ exposure at elevated levels (Shahbaz et al., 2010b). 
60

61

62

63

64

65

66

67

68

69

70

71

72

73

74

75

76

77

78

79

80

81

82

83

84

85

86

87

88

89

Root growth is more severely affected by elevated $\mathrm{Cu}$ than shoot growth and the major proportion of $\mathrm{Cu}$ uptake retains in the root. Increased $\mathrm{Cu}$ contents in the plant tissues induce the synthesis of metal-binding compounds (viz. phytochelatins), which are most likely glutathionederived compounds. (Inouhe, 2005; Ernst et al., 2008). Inductions of phytochelatins presume that more sulfur is needed for synthesis of these compounds, which results into higher absorption, and incorporation of sulfate. Nonetheless, the role of phytochelatins in detoxification of $\mathrm{Cu}$ is not very clear yet (Ernst et al., 2008; Yruela, 2005; 2009; Shahbaz et al., 2010a).

Brassica and other vegetable crops are often grown in the surrounding areas of big cities and industrial areas in developing countries like Pakistan, where they may be subjected to air and heavy metals pollution (Yang et al. 2006). The direct application of sewage water to vegetables is not only the source of many nutrients, but it is often contaminated with high levels of $\mathrm{Cu}$ and other heavy metals. As a result of continues untreated sewage application, heavy metals not only accumulate in the soil but also in vegetables (Younas et al. 1998; Butt et al. 2005). High Cu content in crop plants might not only negatively affect plant growth and functioning, but will also enter the food chain (Brun et al. 2001).

The present study used the hydroponics system which allows very close control over water soluble $\mathrm{Cu}$ and other mineral concentrations as compared to soil-grown system. Cabbage is a very important vegetable in all over the world. In Pakistan, cabbage is cultivated on almost 4.9 thousand hectares with 76.7 thousand tonnes annual production (FAO, 2013). The present study was aimed to investigate the response of growth, pigment contents and sulfur metabolism of Stone-head cabbage grown in hydroponics to the copper exposure.

\section{MATERIAL AND METHODS}

Stone-head cabbage (Brassica oleracea var. capitata $\mathrm{F}_{1}$ ) seeds were germinated to sand in a green house. The seedlings collected at ten days after germination were transferred on an aerated 25\% modified Hoagland nutrient solution in a 11 liter container (15.8" $\mathrm{L}$ x 10.3" W $x$ 7" H; 3 plants set $^{-1}$ and 12 sets container ${ }^{-1}$ ) in a greenhouse for 10 days. The nutrient solution consists of $1.25 \mathrm{mM} \mathrm{Ca}\left(\mathrm{NO}_{3}\right)_{2} .4 \mathrm{H}_{2} \mathrm{O}, 1.25 \mathrm{mM} \mathrm{KNO}_{3}, 0.25 \mathrm{mM} \mathrm{KH}_{2} \mathrm{PO}_{4}, 0$ / $0.5 \mathrm{mM} \mathrm{MgSO} 4.7 \mathrm{H}_{2} \mathrm{O}, 11.6$

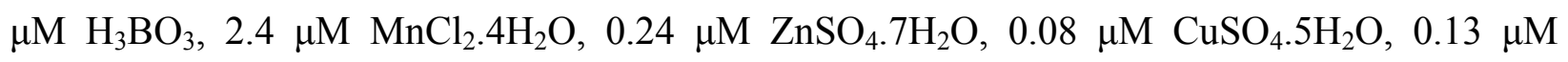
$\mathrm{Na}_{2} \mathrm{MoO}_{4} \cdot 2 \mathrm{H}_{2} \mathrm{O}$ and $22.5 \mu \mathrm{M} \mathrm{Fe}{ }^{3+}$-EDTA with supplemental concentrations of $0,2,5$ and 10 $\mu \mathrm{M} \mathrm{CuCl} 2$ and $\mathrm{pH}$ 5.9-6.0. The nutrient solution was continuously aerated with Aqua-Supreme - 
90 Air Pump - Model AP-4. The photoperiod was $14 \mathrm{~h} .30$ and $25^{\circ} \mathrm{C}\left( \pm 5^{\circ} \mathrm{C}\right)$ temperatures were set

91 for day and night respectively, whereas the relative humidity was maintained at $60-70 \%$.

\section{Pigment contents}

93 Whole shoot was homogenized (in 100\% acetone @ $10 \mathrm{~mL}$ per g FW) followed by 94 centrifugation at $800 \mathrm{~g}$ for 20 minutes. Lichtenthaler (1987) was followed for the determination 95 of chlorophyll $a, b$ and total carotenoid contents.

96 Nitrate and sulfate contents

97 Frozen root and shoot material was homogenized in de-mineralized water $(10 \mathrm{~mL}$ per $\mathrm{g}$ fresh 98 weight) and one layer of Miracloth filter was used to filter the homogenate. The supernatant was 99 incubated in a water bath at $100^{\circ} \mathrm{C}$ for $10 \mathrm{~min}$. The remainder was centrifuged for $15 \mathrm{~min}\left(0^{\circ} \mathrm{C}\right)$ 100 at 30,000 $\mathrm{g}$. The anions were separated by HPLC and Maas et al. (1986) was followed for their 101 refractometric determination using a Knauer differential refractometer (model 98.00, Bad 102 Homburg, Germany).

\section{Water-soluble non-protein thiols}

104 Extraction medium containing $80 \mathrm{mM}$ sulfosalicylic acid, $1 \mathrm{mM}$ EDTA, and $0.15 \%(\mathrm{w} / \mathrm{v})$ 105 ascorbic acid with an Ultra Turrax at $0^{\circ} \mathrm{C}(10 \mathrm{~mL}$ per $\mathrm{g}$ fresh weight $)$ was used for the 106 homogenization of fresh plant matter. The resultant homogenous material was passed through 107 one layer of Miracloth which was then centrifuged at 30,000 $\mathrm{g}$ for $15 \mathrm{~min}\left(0^{\circ} \mathrm{C}\right)$. De Kok et al. 108 (1988) was followed for the determination of total water-soluble non-protein thiol content colorimetrically at $413 \mathrm{~nm}$ after reaction with 5, 5'-dithiobis [2-nitrobenzoic acid].

\section{RESULTS}

\section{Plant biomass in response to $\mathrm{Cu}$ exposure}

113 Exposure of Stone-head cabbage to higher concentrations of $\mathrm{Cu}^{2+}(\geq 2 \mu \mathrm{M})$ in nutrient 114 solution caused chlorosis of both the shoot and young emerging leaves, that ultimately reduced 115 both root and shoot biomass production (Fig. 1). A 10 day exposure to increasing $\mathrm{Cu}^{2+}$ 116 concentrations in nutrient media led to a significant reduction of both root and shoot biomass 117 production at $\geq 2 \mu \mathrm{M} \mathrm{Cu}^{2+}$. Shoot to root ratio improved at $\geq 5 \mu \mathrm{M} \mathrm{Cu}^{2+}$, demonstrating that 118 when exposed to copper, root growth was more affected than shoot growth (Fig. 1). Root dry 119 matter content increased at $10 \mu \mathrm{M} \mathrm{Cu}^{2+}$, whereas shoot dry matter content increased at $\geq 5 \mu \mathrm{M}$ $120 \mathrm{Cu}^{2+}$ (Fig. 2). 


\section{Pigment content in response to $\mathrm{Cu}$ exposure}

122 The total chlorophyll (Chl. $a+b)$ and carotenoids contents of Stone-head cabbage were 123 significantly decreased upon exposure at $\geq 2 \mu \mathrm{M} \mathrm{Cu}^{2+}$ (Fig. 3). There were significant decreases

124 in chlorophyll $a / b$ and chlorophyll/carotenoid ratios when exposed to increased $\mathrm{Cu}^{2+}$ 125 concentrations $\left(10 \mu \mathrm{M} \mathrm{Cu}^{2+}\right)$. Ten $\mu \mathrm{M} \mathrm{Cu}^{2+}$ exposure resulted in the start of rapid development 126 of shoot chlorosis and significantly faster reduction in chlorophyll $a$ contents of chlorophyll $b$ 127 and carotenoids, ultimately leading to a significant reduction in chlorophyll $a / b$ and 128 chlorophyll/carotenoid ratios (Fig. 3).

\section{Sulfate and water-soluble non-protein thiol contents in response to $\mathrm{Cu}$ exposure}

130 Elevated $\mathrm{Cu}^{2+}$ levels showed a significant effect on concentration of the nitrate, sulfate and 131 water-soluble non-protein thiol in stone-head cabbage. The nitrate contents of the roots showed a 132 non significant response to the $\mathrm{Cu}$ exposure at different levels, however in shoots it were 133 significantly decreased at $\geq 5 \mu \mathrm{M} \mathrm{Cu}^{2+}$ (Fig. 4). Sulfate contents in the roots were not affected; 134 however, $\mathrm{Cu}^{2+}$ treatments of $\geq 2 \mu \mathrm{M}$ substantially increased the sulfate contents of the shoot 135 (Fig. 4). There was slight decrease in nitrate to sulfate ratio in the root and a strong decrease in 136 the shoot when exposed to elevated levels of $\mathrm{Cu}$ (Fig. 4). Furthermore, the exposure to $\geq 2 \mu \mathrm{M}$

$137 \mathrm{Cu}^{2+}$ resulted in a solid raise in water-soluble non-protein thiol contents in the roots and to a 138 smaller degree in the shoots at $10 \mu \mathrm{M} \mathrm{Cu}^{2+}$ (Fig. 5).

\section{DISCUSSION}

$140 \mathrm{Cu}$ exposure at elevated levels $\left(<2 \mu \mathrm{M} \mathrm{Cu}^{2+}\right)$ to Stone-head cabbage significantly 141 decreased the production of root and shoot biomass and raised the ratio of the shoot to the root.

142 Copper contamination in the root environment generally results in retarded production of root 143 and shoot biomass and a reduced photosynthetic activity. Moreover, it causes chlorosis, necrosis 144 and bleaching of pigments (Yruela, 2005, 2009; Sheldon and Menzies, 2005; Shahbaz et al. 145 2010a, b). In cabbage, the reduced production of biomass when exposed to elevated $\mathrm{Cu}$ levels 146 coincided with decreased pigment contents (chl a, b, carotenoids; Fig. 3) which may have 147 resulted in reduced activity of photosynthesis and the dark respiration rate (Shahbaz et al., 148 2010a). It has been shown that $\mathrm{Cu}$-toxicity damages chloroplasts either by inducing iron 149 deficiency or by replacing $\mathrm{Mg}$ in the chlorophyll by $\mathrm{Cu}$ (Pätsikkä et al., 2002; Küpper et al., 150 2003). $\mathrm{Cu}$ exposure at elevated levels not only decreased the pigment content but there was also 151 a change in pigment composition. Chlorophyll a content decreased significantly faster than that 
152 of chlorophyll $\mathrm{b}$ and carotenoids, which resulted in a decreased chlorophyll $\mathrm{a} / \mathrm{b}$ and 153 chlorophyll/carotenoid ratio. Similar results were reported by Chu et al. (2006) in Trifolium 154 repens $\mathrm{L}$.

155 It is shown that the production of root biomass was more influenced than that of the shoot 156 biomass production. The relatively higher reduction in the root biomass upon exposure to metal 157 contamination could be due the fact that roots come in direct contact with toxic metals $(\mathrm{Cd}, \mathrm{Cu})$.

158 Toxic metal-induced hindered root growth also reduces the uptake of essential nutrients (Sheldon 159 and Menzies, 2005).

160 Plants have evolved a tightly-controlled mechanism for the absorption, allocation and 161 assimilation of sulfate under normal conditions. (Hawkesford and De Kok, 2006). Enhanced 162 exposure of cabbage to $\mathrm{Cu}$ concentrations considerably affects the contents and allocation of 163 sulfur compounds in the root and shoot of cabbage (Shahbaz et al., 2010a). The raised shoot 164 sulfate contents might be attributed to Cu-toxicity induced upregulation of the sulfate suppliers 165 in roots (Shahbaz et al., 2010a). To maintain rapid growth rates under stress conditions, Brassica species increase their demand for sulfur supply (Koralewska et al., 2008; 2009). Exposure of Stone-head cabbage to elevated levels of $\mathrm{Cu}$ did not affect the nitrate contents in roots, however at $\geq 5 \mu \mathrm{M} \mathrm{Cu}^{2+}$ there was a significant decrease in the shoot nitrate contents. The reduced production of plant biomass at $\geq 5 \mu \mathrm{M} \mathrm{Cu}^{2+}$ could be attributed to reduced supply of nitrate in the shoot. The decrease in nitrate: sulfate ratio in the shoot of Stone-head cabbage under elevated $\mathrm{Cu}$ levels may be attributed to enhanced sulfate contents, however the link between uptake rates of nitrate and sulfate is not evident yet (Stulen and De Kok, 2012). Since both nitrate and sulfate are involved in amino acid and protein synthesis, their uptake rates are related with growth rates

174 (Stulen and De Kok, 2012).

Roots accumulated a slightly raised level of water-soluble non-protein thiols when compared with that of the shoot. Only a small proportion of the rise in thiol content might be attributed to a $\mathrm{Cu}$-induced synthesis of phytochelatins in Chinese cabbage (Shahbaz et al., 178 2010a). Previous reports suggest that the formation of sulfur-rich metal-chelating compounds 179 (i.e. water-soluble non-protein thiols) when disclosed to prospective toxic metals may perhaps 180 require an enhanced demand for sulfur, viz. the absorption rate and incorporation of sulfate 181 (Sirko and Gotor, 2007; Ernst et al., 2008). The possible significance of sulfur nutrition upon 182 elevated copper exposure needs further investigation. 
183

184

185

186

187

188

189

190

191

192

193

194

195

196

197

198

199

200

201

202

203

204

205

206

207

208

209

210

211

212

213

\section{CONCLUSIONS}

This investigation has shown that the elevated copper levels in the root surroundings proved toxic for Stone-head cabbage. Copper exposure at $\geq 2 \mu \mathrm{M} \mathrm{Cu}^{2+}$ negatively affected the plant biomass production and pigment contents. Furthermore, elevated $\mathrm{Cu}$ content considerably affected the concentration of sulfate and water-soluble non-protein thiol of Stone-head cabbage which might be due to the induction of phytochelatins to detoxify excess copper.

\section{REFERENCES}

Brun LA, Maillet J, Hinsiger P,Pépin N. 2001. Evaluation of copper availability to plants in copper-contaminated vineyard soils. Environmental Pollution 111:293-302.

Burkhead J, Reynolds KAG, Abdel-Ghany SE, Cohu CM, Pilon M. 2009. Copper homeostasis. New Phytologist 182(4):799-816.

Butt MS, Sharif K, Bajwa BE, Aziz A. 2005. Hazardous effects of sewage on the environment: Focus on heavy metals and chemical composition of soil and vegetables. Management of Environmental Quality 16: 338-346.

Chu L, Liu DY, Wang YB, Ding JH, Wang LL. 2006. Separate and combined effects of Cu and $\mathrm{Cd}$ on seedling growth and active oxygen metabolism system of Trifolium repens $\mathrm{L}$. Frontiers in Bioscience 11:2861-2867.

Dach J,Starmans D. 2005. Heavy metals balance in Polish and Dutch agronomy: Actual state and provisions for the future. Agriculture Ecosystems and Environment 107: 309-316.

De Kok LD Buwalda F,Bosma W. 1988. Determination of cysteine and its accummulation in spinach leaf tissue upon exposure to excess sulfur. Journalof Plant Physiology 133(4): 502-505.

De Vos CHR,Ten Bookum TM, Vooijs R, Schat H, De Kok LD. 1993. Effect of copper on fatty acid composition and peroxidation of lipids in roots of copper tolerant and sensitive Silenecucubalus. Plant Physiology and Biochemistry 31(2):151-158.

Ernst WHO, Krauss GJ, Verkleij GAC, Wesenberg D. 2008. Interaction of heavy metals with the sulphur metabolism in angiosperms from an ecological point of view. Plant Cell and Environment 31(1):123-143.

Hawkesford, MJ, De Kok LJ. 2006. Managing sulfur metabolism in plants. Plant Cell and Environment 29(3):382-395.

Inouhe M. 2005. Phytochelatins. Brazilian Journal of Plant Physiology 17(1):65-78.

PeerJ reviewing PDF | (2015:02:4041:2:0:NEW 1 Jul 2015) 
214 Kopsell DE,Kopsell DA. 2007. Copper. In: Barker, A.V., Pilbeam, D.J. (Eds.), Handbook of Plant Nutrition. Taylor and Francis Group, Boca Raton, p.p. 293-328.

216 Koralewska A, Buchner P, Stuiver CEE, Posthumus FS, Kopriva S, Hawkesford MJ, De Kok

217 LJ. 2009. Expression and activity of sulfate transporters and APS reductase in curly kale in response to sulfate deprivation and re-supply. Journal of Plant Physiology 166(2):168179

Koralewska A, Stuiver CEE, Posthumus FS, Kopriva S, Hawkesford MJ, De Kok LJ. 2008. Regulation of sulfate uptake, expression of the sulfate transporters Sultr1;1 and Sultr1;2, and APS reductase in Chinese cabbage (Brassica pekinensis) as affected by atmospheric $\mathrm{H}_{2} \mathrm{~S}$ nutrition and sulfate deprivation. Functional Plant Biology 35(4):318-327.

Küpper H, Šetlík E, Šetliková N, Ferimazova M, Küpper FC.. 2003. Copper-induced inhibition of photosynthesis: limiting steps of in vivo copper chlorophyll formation in Scenedesmus quadricauda. Functional Plant Biology 30(12):1187-1196.

Lichtenthaler HK. 1987. Chlorophylls and carotenoids: pigments of the photosynthetic biomembranes. Methods in Enzymology 148:350-382.

Maas FM, Hoffmann I, Van Harmelen MJ, De Kok LJ. 1986. Refractometric determination of sulphate and other anions in plants separated by High-Performance Liquid Chromatography. Plant and Soil 91(1):129-132

Pätsikkä E, Aroan EM, Tyystjärvi E. 1998. Increase in the quantum yield of photoinhibition contributes to copper toxicity in vivo. Plant Physiology 117(2):619-627.

Pätsikkä E, Kairavuo MF, Šerešen EM,Tyystjärvi E. 2002. Excess copper predisposes photosystem II to photoinhibition in vivo by outcompeting iron and causing decrease in leaf chlorophyll. Plant Physiology 129(3):1359-1367.

Pilon M, Abdel-Ghany SE, Cohu CM, Gogolin KA, Ye H. 2006. Copper cofactor delivery in plant cells. Current Opinion in Plant Biology 9:256-263.

Shahbaz M, Tseng MH, Stuiver CEE, Koralewska A, Posthumus FS, Venema JH, Parmar S, HawkesfordMJ, De Kok LJ. 2010a. Copper exposure interferes with the regulation of the uptake, distribution and metabolism of sulfate in Chinese cabbage. Journal of Plant Physiology 167(6):438-446.

Shahbaz M, Tseng MH, Stuiver CEE, Posthumus FS, Parmar S, Koralewska A, Hawkesford MJ, De Kok LJ. 2010b. Impact of copper exposure on physiological functioning of 
Chinese cabbage (Brassica pekinensis). In: More Sustainability in Agriculture: New Fertilizers and Fertilizer Management (Sequi P, Ferri D, Rea E, Montemurro AV, Fornado F. (eds.), 18th International Symposium of CIEC, Fertilitas Agrorum, pp. 318324.

Sheldon A, Menzies NW. 2005. The effect of copper toxicity on growth and morphology of Rhodes grass (Chlorisgayana) in solution culture. Plant and Soil 278(1-2):341-349.

Sirko A, Gotor C. 2007. Molecular links between metals in the environment and plant sulfur metabolism. In: Hawkesford MJ, De Kok J (eds.) Sulfur in plants - an ecological perspective. Springer p. 169-195.

Stulen I, De Kok LJ. 2012. Exploring interactions between sulfate and nitrate uptake at a whole plant level. In: De Kok LJ, Tausz M, Hawkesford MJ, Hoefgen R, McManus MT, Norton RM, Rennenberg H, Saito K, Schnug E, Tabe L (eds.) Sulfur metabolism in plants: Mechanisms and application to food secuirity, and response to climate change. Springer, Dordrecht, pp 1-8.

www.fao.org (http://faostat3.fao.org/download/Q/QC/E) Accessed on 06.23.2015.

Yang L, Stulen I, De Kok LJ.2006. Impact of sulfate nutrition on utilization of atmospheric $\mathrm{SO}_{2}$ as a sulfur source for Chinese cabbage. Journal of Plant Nutrition and Soil Science 169:529-534.

Younas M, Shahzad F, Afzal S, Khan MI, Ali K. 1998. Assessment of Cd, Ni, Cu and Pb pollution in Lahore, Pakistan. Environment International 24: 761-766.

Yruela I. 2005. Copper in plants. Brazilian Journal of Plant Physiology 17(1):145-156.

Yruela I. 2009. Copper in plants: acquisition, transport and interactions. Functional Plant Biology 36(5):409-430. 


\section{Figure 1 (on next page)}

Impact of elevated levels of $\mathrm{Cu}^{2+}$ on biomass production of Stone-head cabbage (Brassica oleracea var. capitata).

10-day-old seedlings of Stone-head cabbage (Brassica oleracea var. capitata) were grown on a $25 \%$ Hoagland solution containing $0,2,5$ and $10 \mu \mathrm{M} \mathrm{CuCl}_{2}$ in the root environment. Data on biomass production ( $\mathrm{g} \mathrm{FW}$ ) and shoot/root ratio represent the mean of 2 independent experiments with 9 measurements having 3 plants in each treatment $( \pm S D)$. Means with different letters differ significantly at $p \leq 0.01$ (Student's t-test). 


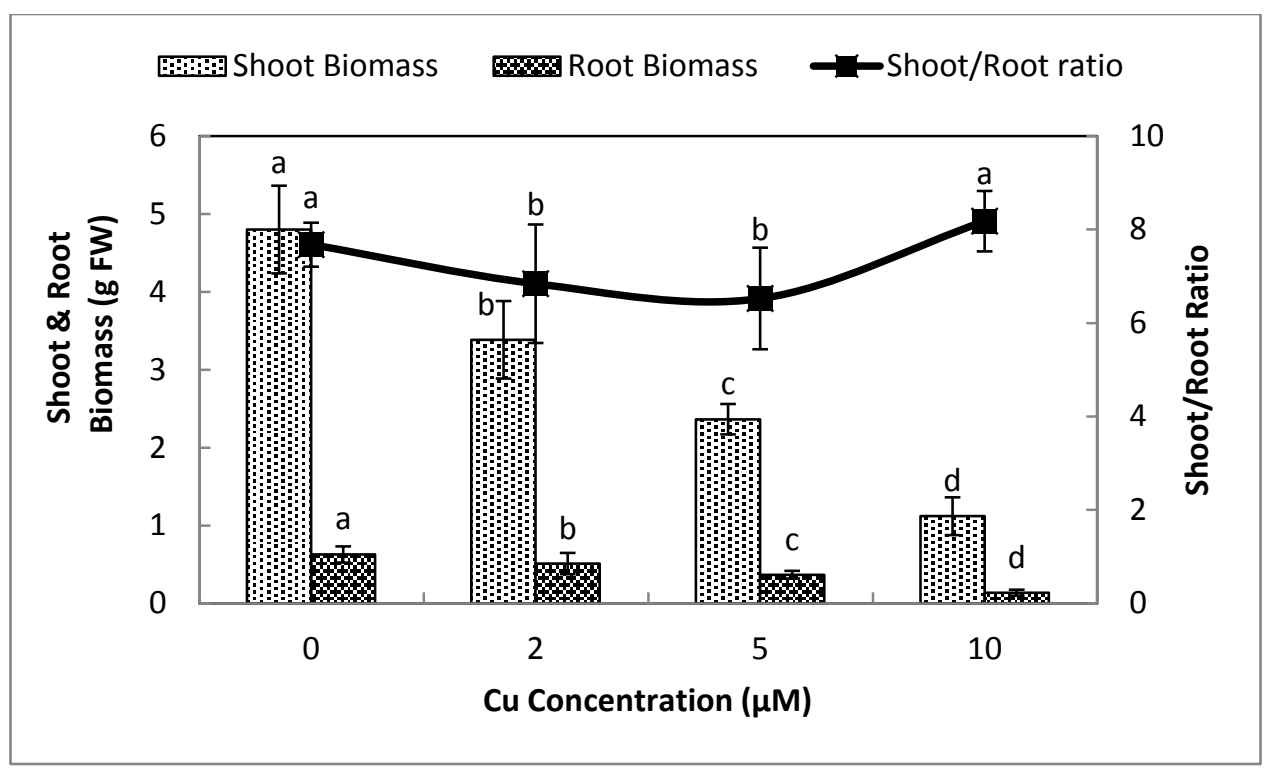


Figure 2 (on next page)

Impact of elevated levels of $\mathrm{Cu}^{2+}$ on dry matter content of Stone-head cabbage (Brassica oleracea var. capitata).

10-day-old seedlings of Stone-head cabbage (Brassica oleracea var. capitata) were grown on a $25 \%$ Hoagland solution containing $0,2,5$ and $10 \mu \mathrm{M} \mathrm{CuCl}_{2}$ in the root environment. Data on dry matter content (\%) represent the mean of 2 independent experiments with 9 measurements having 3 plants in each treatment $( \pm S D)$. Means with different letters differ significantly at $p \leq 0.01$ (Student's t-test). 


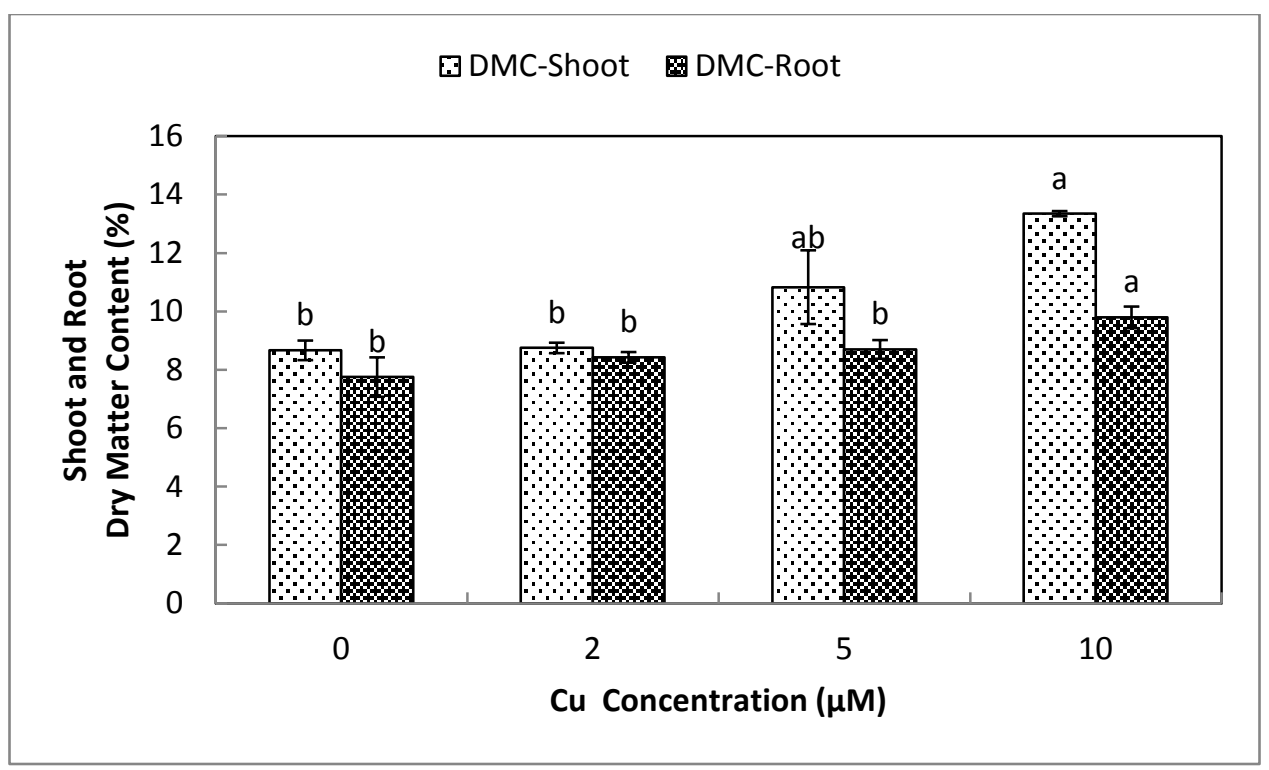




\section{Figure $\mathbf{3}$ (on next page)}

Impact of elevated levels of $\mathrm{Cu}^{2+}$ on pigment content ( $\mathrm{chl} \mathrm{a+b} \mathrm{\&} \mathrm{carotenoids)} \mathrm{of} \mathrm{Stone-}$ head cabbage (Brassica oleracea var. capitata).

10-day-old seedlings of Stone-head cabbage (Brassica oleracea var. capitata) were grown on a $25 \%$ Hoagland solution containing $0,2,5$ and $10 \mu \mathrm{M} \mathrm{CuCl}_{2}$ in the root environment. Data on chlorophyll content ( $\mathrm{chl} \mathrm{a}+\mathrm{b} ; \mathrm{mg} \mathrm{g}^{-1} \mathrm{FW}$ ) and carotenoids content ( $\mathrm{mg} \mathrm{g}^{-1} \mathrm{FW}$ )represent the mean of 2 independent experiments with 9 measurements having 3 plants in each treatment $( \pm \mathrm{SD})$. Means with different letters differ significantly at $p \leq 0.01$ (Student's t-test). 


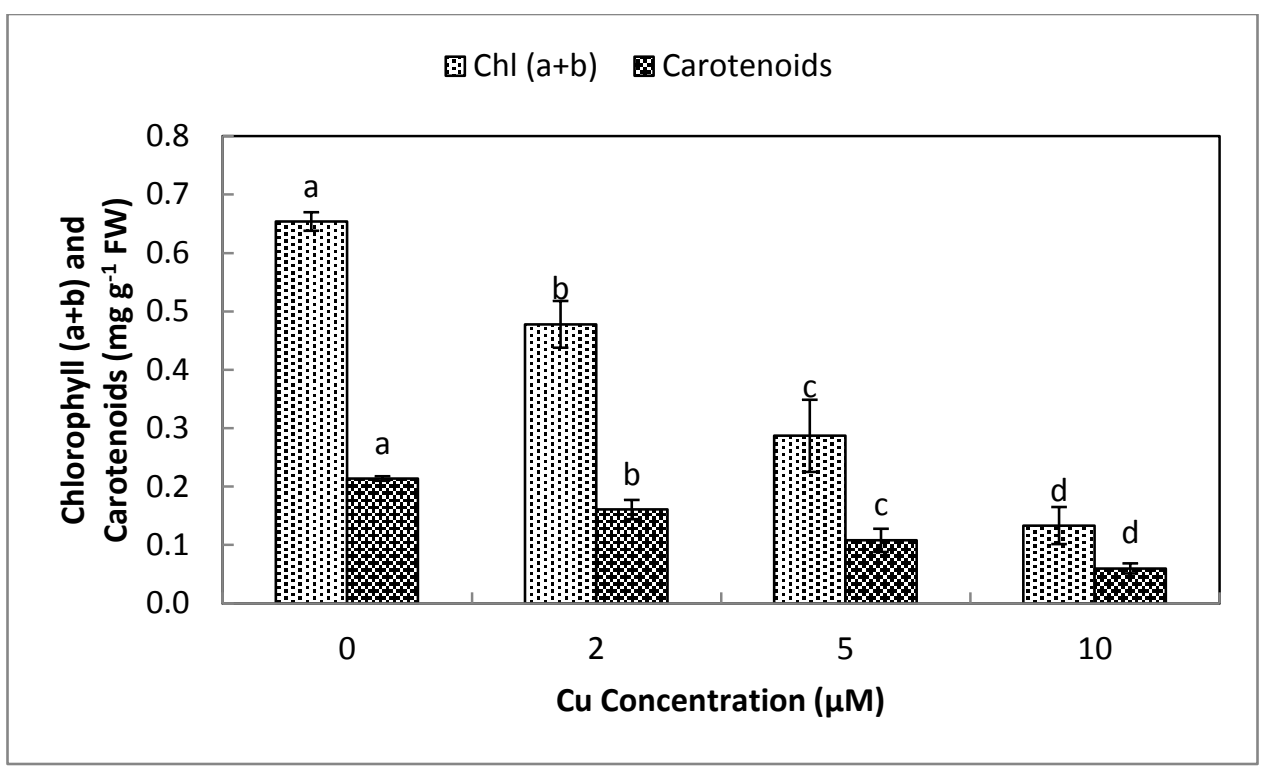


Figure 4 (on next page)

Impact of elevated levels of $\mathrm{Cu}^{2+}$ on pigment content (chla/chlb $\&$ chl/car. ratio) of Stone-head cabbage (Brassica oleracea var. capitata).

10-day-old seedlings of Stone-head cabbage (Brassica oleracea var. capitata) were grown on a $25 \%$ Hoagland solution containing $0,2,5$ and $10 \mu \mathrm{M} \mathrm{CuCl}_{2}$ in the root environment. Data on chlorophyll content (chl a/Chlb and chl/carotenoid ratio) represent the mean of 2 independent experiments with 9 measurements having 3 plants in each treatment ( $\pm S D$ ). Means with different letters differ significantly at $p \leq 0.01$ (Student's t-test). 


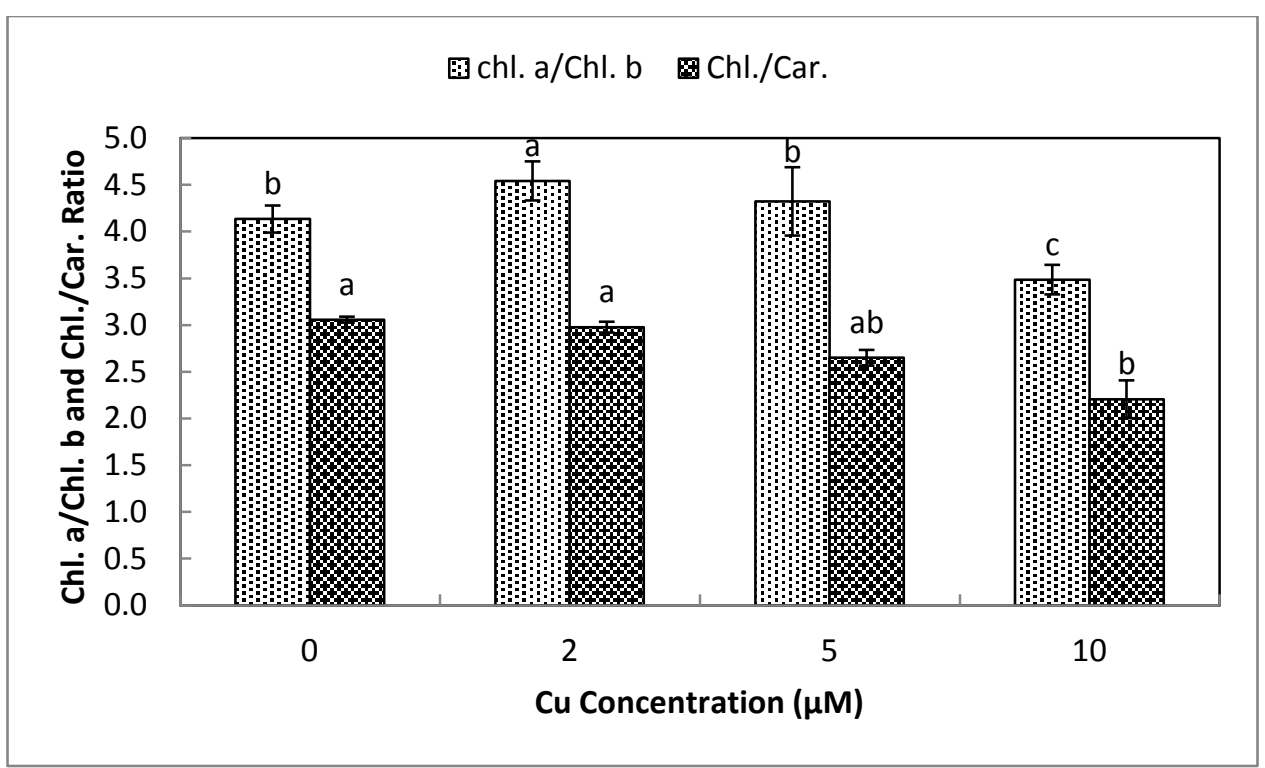




\section{Figure 5 (on next page)}

Impact of elevated levels of $\mathrm{Cu}^{2+}$ on nitrate and sulfate content of Stone-head cabbage (Brassica oleracea var. capitata).

10-day-old seedlings of Stone-head cabbage (Brassica oleracea var. capitata) were grown on a $25 \%$ Hoagland solution containing $0,2,5$ and $10 \mu \mathrm{M} \mathrm{CuCl}_{2}$ in the root environment. Data on nitrate and sulfate content ( $\mu \mathrm{mol} \mathrm{g} \mathrm{g}^{-1} \mathrm{FW}$ ) represent the mean of 2 independent experiments with 9 measurements having 3 plants in each treatment $( \pm S D)$. Means with different letters differ significantly at $p \leq 0.01$ (Student's t-test). 


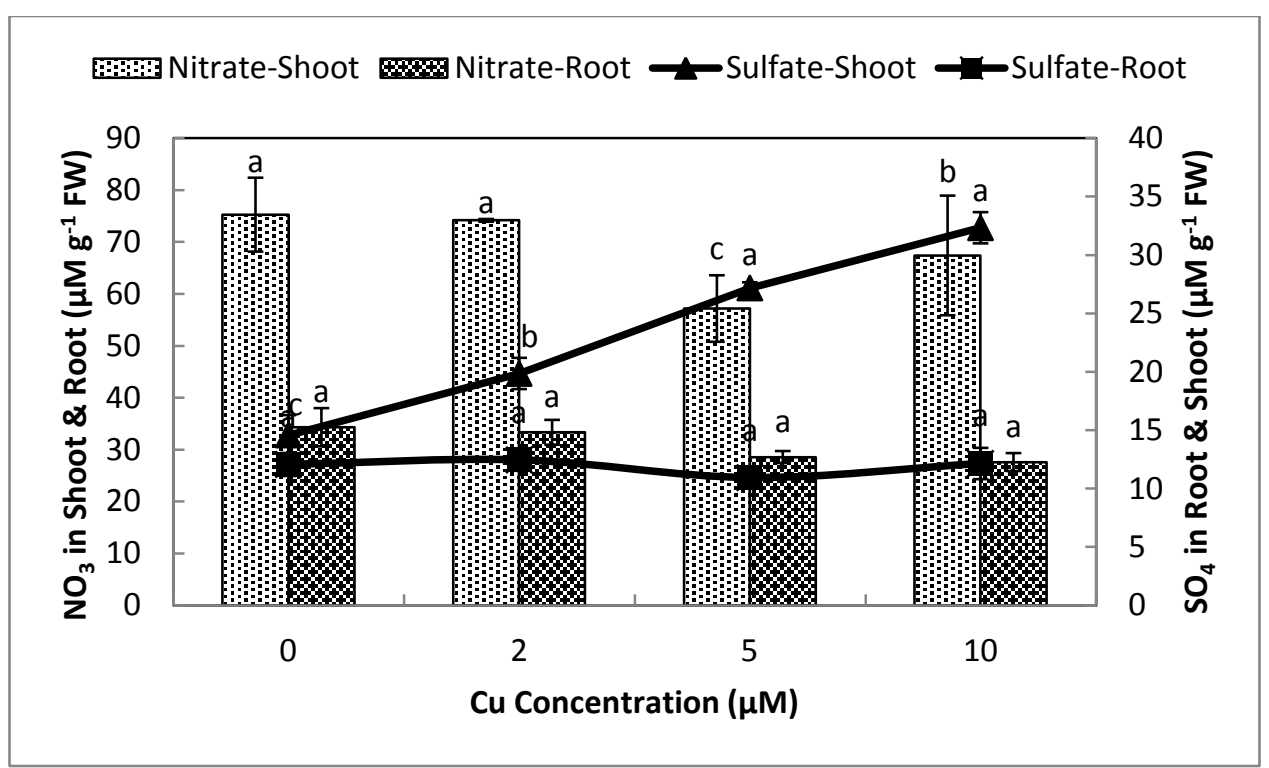

